logos_i_ethos_2020_2_(55), s. 41-62

DOI: http://dx.doi.org/10.15633/lie.3807

Tadeusz Biesaga SDB

https://orcid.org/0000-0003-0863-4422

Uniwersytet Papieski Jana Pawła II w Krakowie

\title{
Roberta Spaemanna próba przywrócenia myślenia teleologicznego we współczesnej filozofii
}

\section{Teleologia natury człowieka przed kryzysem}

Robert Spaemann, analizując różne tematy i wątki w swych publikacjach, demaskuje nieuzasadnione powody usunięcia teleologicznego myślenia z filozofii. Zasadnicze dzieło poświęcone tej tematyce nosi tytuł: Cele naturalne. Dzieje i ponowne odkrycie myślenia teleologicznego ${ }^{1}$. Teleologia przeanalizowana

Tadeusz Biesaga SDB, ks. prof. dr hab. - filozof, etyk, bioetyk, teoretyk etyki medycznej, kierownik Katedry Bioetyki na Wydziale Filozoficznym Uniwersytetu Papieskiego Jana Pawła II w Krakowie. Rozwija personalistyczną etykę, bioetykę i etykę medyczną. Z punktu widzenia personalizmu realistycznego przeprowadza krytykę utylitaryzmu i kontraktualizmu w etyce ogólnej, bioetyce i etyce medycznej.

jest w tym dziele zarówno historycznie, jak i systematycznie, począwszy od starożytności po czasy współczesne. Punktem odniesienia przeprowadzonych analiz jest osiągnięta przez św. Tomasza z Akwinu synteza filozofii Arystotelesa $z$ objawieniem chrześcijańskim. Zdaniem Spaemanna w późnym średniowieczu rozpoczął się proces rozpadu i destrukcji tej syntezy, proces kontynuowany w czasach nowożytnych po współczesne.

1 R. Spaemann, R. Löw, Cele naturalne. Dzieje i ponowne odkrycie myślenia teleologicznego, tłum. A. Półtawski, Warszawa 2008. 
Św. Tomasz, nawiązując do chrześcijańskiego nauczania o stworzeniu, mocniej niż Arystoteles, związał teleologię bytu z Bogiem ${ }^{2}$. „Bóg stworzył formy substancjalne $i$ to, co rzeczywiste; wszczepił on rzeczom ich naturę, dzięki której one same mają swe cele (Zwecke und Ziele). $\mathrm{Na}$ płaszczyźnie rzeczy naturalnych nic się nie zmieniło w stosunku do Arystotelesa, tylko Bóg [- według św. Tomasza - dod. T. B.] nie jest już jedynie causa finalis, w której wieczności istoty starają się uczestniczyć, lecz Bóg jest zarazem causa efficiens, przyczyną sprawczą ich dążenia"3. Arystotelesowskie pojęcie Boga jako ostatecznego celu dążeń wszystkich bytów zostało uzupełnione przez św. Tomasza pojęciem Boga Stworzyciela, ostatecznej Przyczyny Sprawczej. Trudności Arystotelesa, polegające na tym, że Bóg jako najwyższe dobro, może być tylko najwyższym celem, ale sam jako istota doskonała, nie może mieć celów, a więc nie może być przyczyną sprawczą przygodnych rzeczy, św. Tomasz rozwiązał przez teorię bonum diffusivum sui, argumentując, że dobro manifestuje się w udzielaniu siebie. Działanie sprawcze Boga nie polega na stawianiu sobie i realizacji celów wynikających z Jego potrzeb, które dowodziłyby tego, że on czegoś potrzebuje, lecz polega na udzielaniu się Jego miłości, która ujawnia się w stworzeniach. „To udzielanie siebie pisze Spaemann - nie jest niczym innym, jak samoprezentacją Boga poprzez representatio tego, co Boskie, w tym, co skończone [podkr. T.B.]"4. Cele przedmiotów naturalnych są $\mathrm{w}$ nich zaszczepione przez Boga, ale równocześnie są one ich własnymi celami. Celowość natury człowieka przejawia się $\mathrm{w}$ jego actio transiens i actio immanens. To pierwsze działanie urzeczywistnia się $\mathrm{w}$ wytwarzaniu i produkowaniu, to drugie - polega na realizacji najwyższej zdolności człowieka, czyli na teoretycznym poznaniu prawdy, dobra i piękna bytów przygodnych, które odsyłają do prawdy, dobra i piękna absolutnego, czyli do kontemplacji Boga. Uczestnictwo człowieka w tym, co Boskie, przejawia się inaczej niż

2 Por. R. Spaemann, Granice. O etycznym wymiarze działania, tłum. J. Merecki, Warszawa 2006, s. 47.

3 R. Spaemann, R. Löw, Cele naturalne, dz. cyt., s. 94.

${ }^{4}$ R. Spaemann, R. Löw, Cele naturalne, dz. cyt., s. 94-95. 
uczestnictwo bytów nieświadomych, u których szczytem jest rozwój ich natury wegetatywnej czy sensytywnej. Chwalą one Boga swym istnieniem i rozwojem, a człowiek chwali Go nie tylko swym istnieniem i rozwojem, lecz także dążeniem do Jego kontemplacji, w czym zawiera się otwarcie na łaskę i Jego objawienie. W tym miejscu to, co naturalne, i to, co nadprzyrodzone, bez przeszkód spotykają się ze sobą i wzajemnie się dopełniają.

W ten sposób św. Tomasz w swej syntezie myśli starożytnej z chrześcijaństwem połączył starożytną koncepcję uczestnictwa z chrześcijańską nauką o stworzeniu. Rozwiązał problem teleologii immanentnej przyrody, wyjaśniając, kto pchnął ją do istnienia i nadał bytom określoną naturę i kierunek. Realizacja reprezentacji tego, co pochodzi od Boga przez byty skończone, polega na realizacji swej natury, swej formy. Różne byty przyrody martwej, przyrody ożywionej czy człowiek, spełniając siebie, w różny sposób partycypują, czyli uczestniczą w tym, co Boskie. Dla człowieka szczytem tego uczestnictwa w tym, co Boskie, jest spełnienie w sobie najwyższej swej zdolności, czyli zdolności teoretycznego poznania i kontemplacji prawdy, dobra i piękna, w tym prawdy, dobra i piękna ostatecznego, a więc kontemplacji Boga.

Teleologiczne ujęcie bytu zarówno dla Arystotelesa, jak i św. Tomasza było w ich filozoficznym rozumieniu rzeczywistości czymś centralnym. Celowe działanie porządkowało bowiem pozostałe przyczyny istnienia i działania bytu, w tym również działania człowieka. Wśród czterech przyczyn, czyli przyczyny materialnej odpowiadającej na pytanie: „z czego jest”?, przyczyny formalnej odpowiadającej na pytanie: „czym jest?”, przyczyny sprawczej odpowiadającej na pytanie: „przez co jest?”, przyczyna celowa odpowiadała, można rzec, na najważniejsze filozoficznie pytanie: „po co jest, ze względu na co jest?”5. Nic dziwnego, że była ona określana jako causa causarum, przyczyna przyczyn, gdyż bez niej nie

5 Por. P. Gondek, Kontekst odkrycia przyczyny celowej, w: Spór o cel, red. A. Maryniarczyk SDB, K. Stępień, P. Gondek, Lublin 2008, s. 112 (Zagadnienia Współczesnej Metafizyki, 10). Obszerne opracowanie przyczynowania kauzalno-skutkowego i celowościowego, przeprowadzone od strony filozofii i metodologii nauki, znajdujemy w: Z. Wróblewski, O pewnej próbie obrony wyjaśniania teleologicznego, „Roczniki Filozoficzne” 60 (2012) nr 4, s. 339-359. Z czterech przyczyn artykuł 
dało się zrozumieć ruchu, a w nim działania człowieka, jego transcendencji, nie dało się pojąć dobra, do którego człowiek dąży, które w tej perspektywie było usytuowane. To właśnie dobro-cel wyzwala i tłumaczy działanie bytu ludzkiego, wytrąca wolę ludzką przez pożądanie dobra z bierności (pierwsza miłość), drogą samodeterminacji woli ludzkiej wyzwala działanie sprawcze człowieka, oraz przez dobór celów pośrednich, przyporządkowanych do celu finalnego, ostatecznego, włącza aktualne środki realizacji celu-dobra, czyli określoną materię i formę rzeczy przyporządkowaną temu celowi.

Spaemann objaśnia działanie ludzkie, rozróżniając cele finalne (Ziele) i cele instrumentalne (Zwecke). Jego zdaniem Arystotelesowskiemu odróżnieniu finis quo i finis cuius odpowiada rozróżnienie między celem instrumentalnym i celem finalnym, czyli rozróżnienie celu i ,ze względu na...” „"Cel finalny» - stwierdza on - byłby owym «ze względu na...», które zawsze znajdujemy i w obrębie czego możemy się w ogóle dopiero rozumieć jako istoty żywe. "Cel instrumentalny» byłby natomiast celem świadomie ustalonym i przełożonym na konkretną orientację działania. Ustalając cele instrumentalne, rozglądamy się za środkami, podczas gdy cel finalny poprzedza tamten jako podstawa umożliwiająca dualizm celów i środków"6. W wyjaśnieniu działania przyczynowanie celowe scala więc pozostałe przyczyny działania człowieka i analogicznie każdego bytu, czyli przyczynę sprawczą, wzorczą, materialną i formalną, uzasadniając dlaczego realne działanie zachodzi i przez co jest ono zrozumiałe ${ }^{7}$. Różnica między istotami żywymi jest tylko taka, że zwierzęta i rośliny odnoszą się do swych celów finalnych immanentnie, bezpośrednio, natomiast człowiek jako istota świadoma, odnosi się do swego celu transcendentnie, za pośrednictwem tego, co formułuje on w świadomej refleksji nad powinnością realizacji dobra, którego doświadcza.

ten omawia tylko dwie: przyczynę sprawczą - causa efficiens oraz przyczynę celową - causa finalis i konfrontuje ze sobą wyjaśnianie przyczynowe, kauzalne z wyjaśnianiem teleologicznym (s. 342nn).

6 R. Spaemann, R. Löw, Cele naturalne, dz. cyt., s. 324.

7 Por. M. A. Krąpiec, Problematyka celu w wyjaśnianiu filozoficznym, w: Spór o cel, dz. cyt., s. 32 . 
W dokonanej przez św. Tomasza obszernej i trudnej syntezie koncepcji Boga, człowieka i przyrody wystarczyło inaczej zinterpretować któryś z jej elementów, którąs z czterech przyczyn, aby synteza ta się rozsypała. Destrukcja tej syntezy rozpoczęła się już pod koniec średniowiecza i była kontynuowana w późniejszych okresach filozofii, pogłębiając coraz bardziej rozbicie systemu filozoficznego zaproponowanego przez św. Tomasza. W tym zawirowaniu szczególnie ucierpiało rozumienie teleologii bytu, w tym teleologii człowieka, którą w różny sposób zniekształcano, aż w końcu wyrugowano i zastąpiono antyteleologią .

\section{Powody usunięcia teleologii z myślenia filozoficznego}

Zdaniem Spaemanna destrukcję teleologii rozpoczęli pod koniec średniowiecza nominaliści m.in. Wilhelm Ockham i Jan Buridan" Ten drugi nawiązał do Averroesowej interpretacji celowości w filozofii Arystotelesa. Zasadnicze bowiem w filozofii Stagiryty było rozumienie finis cuius i finis quo. Avicenna w poszukiwaniu odpowiedzi na pytanie, jak może finis quo działać, kiedy on jeszcze nie istnieje, podważył funkcjonowanie przyczyny celowej. Jeśli człowiek zamierza zbudować dom, antycypując jego budowę, to nieistniejący dom nie może poruszać działania, bo on jeszcze nie istnieje, natomiast zamiaru sprawcy nie można nazwać przyczyną celową, lecz stanem antycypacji domu w świadomości działającego, a taki stan podmiotu nie jest przyczyną celową, ale przyczyną sprawczą realizacji domu. $\mathrm{W}$ ten sposób przyczynowanie celowe zostało zredukowane do przyczynowania sprawczego ${ }^{10}$.

Nominaliści pogłębiali tę redukcję, akcentując świadome przyczynowanie sprawcze Boga. Według nich pojęciu finis nie odpowiada nic w poznawanej przez nas rzeczywistości. Istnieją tylko przedmioty jednostkowe, a pojęcia ogólne służą nam tylko porządkowaniu tych

8 Por. W polskiej literaturze przedstawia to m.in. H. Jakuszko, Źródła i skutki odrzucenia przyczyny celowej w filozofii nowożytnej, w: Spór o cel, dz. cyt., s. 35-56.

9 Por. R. Spaemann, Granice, dz. cyt., s. 47.

10 Por. R. Spaemann, R. Löw, Cele naturalne, dz. cyt., s. 105-106. 
przedmiotów, umieszczaniu ich w klasy, jednak pojęciom tym nie odpowiada nic realnego. Przypisywanie przyrodzie działania celowego, to ich zdaniem - antropomorfizm, to nadawanie jej cech boskich, to idolatria i bezbożność. Przyroda posiadająca własne cele ograniczałaby wszechmoc Boga i przeczyła jej. W ten sposób, z pozycji teologicznych i epistemologicznych, nominaliści pozbawili przyrodę i naturę bytów ich własnej celowości, szerzej - ich własnej wartości czy dobra.

Skonfliktowanie teleologii rzeczy z samotranscendencją Boga szybko przerzuciło się na konflikt teleologii z samotranscendencją człowie$\mathbf{k a}^{11}$. Pozbawiono rzeczy ich własnej natury i podporządkowano je celom ustanawianym przez człowieka. Od czasów Bacona i Kartezjusza przyczynowanie celowe rzeczy zostało uznane jako wrogie człowiekowi. Człowiek powinien opanować ślepe siły przyrody, które zagrażają jego życiu. Świat, a nawet ciało ludzkie, zostało zredukowane do maszyny. Wiedza ma służyć podbojowi przyrody i panowaniu człowieka. „Technologiczne panowanie nad naturą umotywowane zostało pragnieniem zapewnienia przetrwania ludzkości" ${ }^{12}$.

Przetrwanie najlepiej przystosowanych stało się w terminologii Darwina istotną cechą dynamizmów przyrody. Owo samozachowanie zastąpiło cel ostateczny człowieka, który Arystoteles i św. Tomasz upatrywali w uczestnictwie w tym, co Boskie. Tę karykaturę teleologii współcześni biologowie nazywają teleonomią. W treści tego pojęcia podkreśla się, że to człowiek dla swego przetrwania wyznacza cele naturze, ona bowiem żadnych celów w sobie nie posiada.

Już Arystoteles odróżniał dążenie do przetrwania od samotranscendencji. Odróżnił on życie od dobrego życia. Cel człowieka to coś więcej niż unikanie śmierci. „Dobre życie lub najlepsze życie to kontemplacja lub theoria; zapominająca o sobie (i przez to samotranscendentna)

11 Problem relacji osoby (świadomości, wolności) do natury człowieka, związku autoteleologii osoby z teleologią natury ludzkiej wymaga osobnego opracowania, dla którego jednym z podstawowych dzieł jest publikacja: R. Spaemann, Osoby. O różnicy między czymś a kimś, tłum. Jarosław Merecki SDS, Warszawa 2001.

12 A. Ramelow OP, Teleology and transcendence: the thought of Robert Spaemann, „Communio: International Catholic Review" 45 Fall-Winter 2018, s. 574. 
kontemplacja pierwszej przyczyny" ${ }^{13}$. Realizację tych celów Stagiryta widział w życiu politycznym, które umożliwia przyjacielską samotranscendencję względem drugich.

O ile dla Arystotelesa celem wiedzy teoretycznej była kontemplacja, o tyle już dla Fracisa Bacona wiedza stała się narzędziem podboju przyrody i wzrostu potęgi człowieka. Thomas Hobbes odrzucił nawet przyjaźń jako spełnienie człowieka, podporządkowując ją dążeniom do przetrwania. Nie wszyscy mogą przetrwać, lecz tylko nieliczni, stąd również przyjaźń, tak jak inne sprawności, należy wykorzystać do przetrwania najsilniejszych czy najsprytniejszych. Biologiczne indywidualne czy grupowe przetrwanie wyrugowało wyższe cele w myśleniu i działaniu człowieka.

Fryderyk Nietzsche - zdaniem Spaemanna - taką moralność nazwał "moralnością niewolników”. Niewolnik jest niewolnikiem dlatego, że lęka się śmierci, i stąd jest poddany tyranowi. Tyran żywi się naszym lękiem przed śmiercią. Stajemy się przez to niewolnikami, ponieważ bardziej lękamy się śmierci niż złego życia.

Jeśli zachowanie życia stało się w tym ujęciu celem ostatecznym, nic dziwnego, że cel ten znika wraz z zakończeniem życia. Zdaniem nihilistów w naszym nieistnieniu nie ma nic wewnętrznie złego. „Morderstwo nie jest przemocą, ponieważ zarazem eliminuje życie jak i pragnienie życia" ${ }^{\prime 4}$. Temu myśleniu ulegają - zauważa Spaemann - również współcześni zwolennicy eutanazji, argumentując, że należy wyeliminować czyjeś cierpienie przez eliminację cierpiącego ${ }^{15}$.

Okazuje się jednak, że przetrwanie jako cel potrzebuje dalszego usprawiedliwienia. Bez niego taki cel zostaje podporządkowany ślepemu, irracjonalnemu instynktowi. Już Arystoteles wskazywał na istnienie takiego celu. „Actus primus istnienia jest z powodu drugiego celu, którym jest rozwój naszej natury: omne ens est propter suam propriam operationem.

13 A. Ramelow OP, Teleology and transcendence: the thought of Robert Spaemann, dz. cyt., s. 576.

14 A. Ramelow OP, Teleology and transcendence: the thought of Robert Spaemann, dz. cyt., s. 576.

15 Zob. T. Biesaga, Eugenika w propozycjach legalizacji prawa do zdrowej reprodukcji, „Logos i Ethos" 50 (2019) nr 2, s. 27-46 
Przetrwanie jest z powodu dobrego i owocnego życia, «zen» jest z powodu «eu zen». Współczesny pogląd odwraca ten związek, co Spaemann nazywa inwersją «odwróceniem teleologii», lub w sformułowaniu, które zaczerpnął od Adorno i Horkheimera - «podporządkowaniem życia warunkom jego przetrwania»" 16 .

Arystoteles zaprzeczał temu, aby samozachowanie dało się zamknąć w skierowaniu na siebie i tym uzasadnić. Według niego uzasadnieniem naszego trwania jest realizacja uczestnictwa w odwiecznym życiu Boga. Pragnienie kontynuacji swego istnienia było uzasadniane reprezentacją w naszym istnieniu i działaniu istnienia Bytu Absolutnego. „Średniowiecze traktuje akt istnienia bytu przygodnego jako ograniczoną reprezentację bytu nieograniczonego i jako odpowiedź wobec Bożego kreatywnego aktu przyczynowości sprawczej, której ostatecznym celem jest jego bonum as diffusivum sui. Samo istnienie jest niezrozumiałe bez ostatecznego celu i samotranscendencji, która ma swoją kulminację w zetknięciu się ze swym źródłem, w żywym doświadczeniu tej bliskości i dystansu, który charakteryzuje wszelki byt" ${ }^{17}$.

Odwrócenie i zacieśnienie teleologii do samozachowania siebie podważyło transcendencję natury ludzkiej, i w miejsce dążenia do reprezentacji tego, co nieskończone, czyli w miejsce uczestnictwa w życiu Boga i Jego kontemplacji, pchnęło człowieka do walki o byt, do agresywnego podboju przyrody, do budowania raju na ziemi. Myślenie to stworzyło mentalność terrystyczną, mentalność walki, podoju, technokratycznej agresji względem przyrody oraz przeprowadzania programów inżynierii społecznych w duchu różnych „wyzwoleńczych" ideologii. Inwersja celowości w swojej cyrkulacji zwróconej nie na dobre życie, lecz na przetrwanie silniejszych, zamiast wyzwolić człowieka coraz bardziej wzmacniała instynktowny egoizm drapieżnego, rozumnego zwierzęcia. Do dziś jesteśmy w oparach wyzwoleńczej walki klas, wyzwalania się ze swej cielesności, płciowości, kobiecości czy męskości.

16 A. Ramelow OP, Teleology and transcendence: the thought of Robert Spaemann, dz. cyt., s. 576.

17 A. Ramelow OP, Teleology and transcendence: the thought of Robert Spaemann, dz. cyt., s. 577. 


\section{Skutki teoretyczne i praktyczne usunięcia teleologii}

Wyrugowanie myślenia teleologicznego z ujęcia bytu, w tym również z ujęcia natury człowieka, przyniosło niszczące skutki zarówno dla przyrody, dla istot żywych, jak i dla istoty cielesno-duchowej, jaką jest homo sapiens. Teleologia unaoczniała pluralizm bytów oraz domagała się szacunku dla ich różnorodności i inteligibilności. Wyznaczała ona to, co jest dobre dla każdego bytu, i określała granice samowoli człowieka. Zgodnie z tym myśleniem każdy byt posiada swoją formę substancjalną, entelechię ukierunkowującą go do swego celu: „Każda forma substancjalna posiada konstytutywne skierowanie, które ustanawia normatywne kryteria oceny (tej róży/geparda/dorosłej kobiety, tego, czy postępuje dobrze, czyli czy to ono, on, ona realizuje swój właściwy telos)"18. To, co jest animowane - czy to animowane przez duszę wegetatywną, sensytywną czy racjonalną - jest skierowane przez formę swego bytu do właściwego sobie celu, który każda istota żywa rozwija w swym życiu, dopóki żyje.

Kartezjusz zacieśnił pluralizm bytów, dzieląc je na te, które mają świadomość (res cogitans), i na te, które jej nie posiadają (res extensa). $\mathrm{W}$ tym radykalnym dualizmie i antropocentryzmie również człowiek został odarty z czegoś podstawowego, czyli z życia. Człowiek bowiem najpierw musi żyć, aby myśleć, a nie odwrotnie. W zacieśnieniu człowieka do res cogitans ucierpiało jego ciało, a wraz z nim ucierpiały wszystkie istoty żywe, gdyż zostały zredukowane do materialnej rozciągłości i potraktowane jako maszyny. W ten sposób natura istot żywych została pozbawiona życia i tego, co w niej jest zasadnicze, spontanicznego skierowania do właściwego sobie celu, a więc skierowania do pełnej realizacji potencjalności tkwiących w entelechii istoty żywej.

Zacieśnione ujęcie natury człowieka i istot żywych prowadziło do podporządkowania mechanicznym prawom fizyki tego, co jest rozciągłe, co nie jest myślą. W tym monizmie materialistycznym zatarto różnice

18 T. P. S. Angier, Book Reviews: A Robert Spaemann Reader: Philosophical Essays on Nature, God, and the Human Person, ed. and transl. by D.C. Schindler \& Jeanne Heffernan Schindler, OUP, Oxford 2015; „The Philosophical Quarterly” 68 (2018) no. 270, s. 194. 
między poszczególnymi istotami żywymi, uznano bowiem, że wszystkie one zbudowane są z tego samego materiału, z materii, i podlegają tym samym prawom przyczynowym.

Według Spaemanna filozofowie już od XVIII wieku oscylowali w swej antyteleologicznej koncepcji natury między redukcjonizmem naturalistycznym, redukującym zjawiska do ruchu materii, którego przykładem jest filozofia Hobbesa czy Hume’a, a spirytualistycznym transcendentalizmem, zmierzającym do wyrwania człowieka $\mathrm{z}$ owych deterministycznych praw przyrody, którego przykładem jest choćby filozofia Kanta ${ }^{19}$.

Jeśli nawet naturaliści próbowali dostrzec $\mathrm{w}$ naturze istot żywych czy w naturze człowieka jakieś namiastki celowości, to i tak były one ciasno pojmowane, jako ślepe siły instynktów, takich jak instynkt samozachowawczy, instynkt posiadania, instynkt seksualny czy instynkt władzy. W miejsce myślenia pluralistycznego, myślenia entelechią poszczególnych bytów ożywionych, posiadających różnorodne ukierunkowywania do swoistych dla siebie celów, wchodziło myślenie monistycznie, w którym instynkt samozachowawczy u ludzi czy u zwierząt jest taki sam i tak samo funkcjonuje. Łatwo dostrzec dziś wpływ tego myślenia na współczesne zacieranie różnic między człowiekiem a zwierzęciem.

Hobbes twierdził, że człowiek nie posiada żadnego summum bonum, lecz jedynie kroczy on w nieskończonym postępie od pożądania do pożądania, od potrzeby do potrzeby. To właśnie owo nieskończone parcie do panowania nad przyrodą i realizacji swych pożądań, usuwało z niej jej własne cele, które człowiek winien respektować. Aby owo rozpasane i nieustanne parcie instynktów i egoizmów ludzkich nie prowadziło do samozagłady ludzi, filozof zaproponował stworzenie konwencjonalnego państwa - Lewiatana. Egoiści powinni zrzec się wszystkich swoich uprawnień na rzecz owego despoty, który ujarzmi drapieżników i zapewni większej ich części przetrwanie. Tak więc zniesienie granic wyznaczonych teleologią bytu i teleologią natury ludzkiej kończy się absolutyzmem państwowym, w którym wyrugowano te dobra czy

19 Por. T. P. S. Angier, Book Reviews: A Robert Spaemann Reader: Philosophical Essays on Nature, God, and the Human Person, dz. cyt., s. 195. 
wartości, które mogłyby ograniczyć samowolę państwa. Wraz z utratą celowości natury ludzkiej utracono tym samym podstawy normatywności i moralności i zastąpiono je konwencją - umową społeczną.

W tym ujęciu nie chodziło już o dobre życie, ale o przeżycie, które miało umożliwić silne, despotyczne państwo. Cnoty, które miały usprawniać ludzi do dobrego życia, zostały wyśmiane i usunięte $\mathrm{z}$ systemów etycznych, z życia indywidualnego i społecznego ${ }^{20}$. Egzystencja i moralność człowieka zostały podporządkowane warunkom biologicznego przetrwania. Ponieważ państwo miało gwarantować owo przetrwanie maksymalnej liczby egoistów, stąd obiektywne zasady moralne zastąpiono prawem stanowionym.

Również transcendentalny antropocentryzm nie uchronił człowieka i innych istot żywych przed despotycznymi regułami stosowanymi wobec mechanistycznie rozumianej przyrody. Stało się to dlatego, że w świecie, w którym nie napotykamy celów naturalnych, natura staje się bezbronna. Nie znając dóbr, na które wskazują naturalne cele istot żywych, cele natury ludzkiej, nie mamy możliwości stwierdzić tego, że przekraczamy wskazane nimi granice i dokonujemy na niej gwałtu. Natura odarta $\mathrm{z}$ celów jest aksjologicznie i normatywnie neutralna i bezbronna, a do tego traktowana jako zagrażająca człowiekowi. Musi się więc stać przedmiotem panowania i samowoli człowieka. Podbój takiej nieuporządkowanej przyrody traktowany jest jako twórcze, a może i stwórze dzieło wolności ludzkiej. „Cywilizacja techniczna, ekspansja panowania nad naturą - stwierdza jeden z teoretyków - opiera się ciągle na utopii, że istnieje rozdział pomiędzy wolnością i naturą"21.

Mimo dążeń transcendentalnego antropocentryzmu, aby wynieść człowieka na szczyt hierarchii bytów, wysiłki te spełzły na niczym, gdyż uprzedmiotowiono istotną jego strukturę, czyli jego ciało, uznając je za wroga jego wolności. To, co działo się w technokratycznym,

20 Zob. T. Biesaga, Alasdaira MacIntyre’a krytyka etyki nowożytnej i współczesnej, w: T. Biesaga, Podstawy etyki i bioetyki, Kraków 2016, s. 15-29.

21 Z. Teinert, Spór o naturę. Wokół konstytucji osoby w ujęciu Roberta Spaemanna, Poznań 2003, s. 216. 
rabunkowym podboju przyrody, przenosiło się tym samym na podobne, rabunkowe uprzedmiotowienie cielesności ludzkiej. Nie tylko przyrodę, w tym istoty żywe, potraktowano jako materiał realizacji celów technicznych, ale potraktowano tak również ciało ludzkie. Człowiek został ujęty jako „ja” transcendentalne, jako „duch” wrzucony w maszynę. Ciało tak rozumiane zostało poddane i wpisane, tak jak inne przedmioty materialne, $\mathrm{w}$ ramy korzyści czy niekorzyści, w ramy kalkulacji utylitarystycznych. Przyrodę, istoty żywe, w tym ciało ludzkie, podporządkowano optymalizacji preferencji owego „bóstwa”, jakim jest „ja transcendentalne".

Przeciw filozofii transcendentalnej Spaemann stwierdza: „Ludzie nie są duchami, które od wewnątrz poruszają pewną maszynę. Są istotami żyjącymi, a to oznacza, że ich podmiotowość nie jest czystą, transcendentalną wolnością, która staje wobec świata faktów zewnętrznych"22. Kiedy wybieramy między celami, to „w rzeczywistości wcale nie ustanawiamy celów, lecz znajdujemy je już w sobie i w innych - znajdujemy je w postaci popędu. Możemy się, co prawda, od niego zdystansować. Fakt, że jesteśmy głodni, nie zmusza nas do jedzenia"23. Brak przymusu nie neguje tego, że pożywienie jest dla nas dobrem. „Popęd jest naturalnym faktem, który ma już charakter wektorowy, sensownie ukierunkowany (Richtungssinn hat). Dlatego popęd uzasadnia regułę, która rozkłada ciężar uzasadnienia"24.

Usunięcie teleologii bytu oraz ostatecznego celu człowieka zniekształciło nie tylko koncepcję człowieka, ale zawęziło również koncepcję rozumu. Egoistycznie ukierunkowany rozum instrumentalny, utraciwszy swoje zdolności kontemplacji przyrody i kontemplacji natury oraz godności człowieka czy wielkości Boga, przyporządkowywał wszystko zasadom korzyści, zdobyczy i władzy. Zarówno technika, jak i sztuka nie tylko oderwały się od kontemplacji przyrody jako wielkiego daru

22 R. Spaemann, R. Löw, Cele naturalne, dz. cyt., s. 200. Rozumienie wolności zob. R. Spaemann, Osoby, dz. cyt., s. 241-271.

23 R. Spaemann, R. Löw, Cele naturalne, dz. cyt., s. 200.

24 R. Spaemann, R. Löw, Cele naturalne, dz. cyt., s. 200. 
i dobra, ale rzuciły się agresywnie na zmienianie świata. Zastany, ślepy świat przypadkowych procesów kosmicznych nie był już domem, lecz zagrożeniem. W kontekście lęku o przetrwanie ateistyczne ideologie zaczęły tworzyć programy podboju przyrody i budowy raju na ziemi, czy to raju komunistycznego, czy to kapitalistycznego. Postęp nauk ścisłych i technicznych niejako potwierdzał wzrost potęgi człowieka i słuszność obranej drogi. W ten sposób powstające ideologie łatwo nazywały się teoriami naukowymi.

Prowadziło to nie tylko do agresywnej eksploatacji przyrody, lecz także do podobnego, biotechnologicznego zawładnięcia ciałem ludzkim. Odarcie natury ludzkiej z jej wewnętrznej celowości otwarło drzwi do agresywnego traktowania zarówno swojego ciała, jak i ciała drugich osób. Przykładem tego jest nie tylko masowe, przemysłowe wykorzystanie ciał zamordowanych więźniów w nazistowskich, niemieckich obozach koncentracyjnych, ale i współczesne wykorzystywanie ciał dzieci $\mathrm{z}$ okresu prenatalnego $\mathrm{w}$ przemyśle aborcyjnym, farmaceutycznym czy kosmetycznym, w handlu parzystymi narządami do transplantacji, pobieranymi z żywych dawców z biednych krajów. Tendencja ta ujawnia się zarówno w ideologii transczłowieka, jak i w propagowaniu manipulacji swoją płciowością ${ }^{25}$. Przez utratę teleologii ciała w strukturze człowieka ciało ludzkie stało się bezbronnym, aksjologicznie neutralnym materiałem biologicznym.

W podporządkowywaniu ciała subiektywnym i komercyjnym celom wyznaczonym przez człowieka potraktowano go jako środek dostarczania przyjemności czy korzyści. Już Epikur zauważył, że przyjaźń jest czymś więcej niż przyjemnością i przekracza ona nasze poszukiwania tych przeżyć. „Platon, Arystoteles i stoicy - pisze Spaemann - wprowadzili jednak nowe pojęcie tego, co słuszne $z$ natury. Opiera się ono na dwu przesłankach. Pierwsza z nich mówi, że w naturze subiektywna przyjemność ma zawsze swoją funkcję, tj. jest zakorzeniona w obiektywnej teleologicznej konstytucji indywidualnej physis. Głód i przyjemność

25 Zob. T. Biesaga, Natura osoby ludzkiej a ulepszanie człowieka, w: Ulepszanie człowieka. Perspektywa filozoficzna, red. G. Hołub, P. Duchliński, Kraków 2018, s. 169-198. 
płynąca z jego zaspokojenia jest funkcją zachowania życia, rozkosz seksualna jest funkcją zachowania gatunku, zadowolenie płynące z pewnego rzemiosła jest funkcją obiektywnej teleologii tego rzemiosła. Przyjemność jest subiektywnym sposobem przeżywania realizacji obiektywnego telos” ${ }^{26}$. Według Arystotelesa „nieszczęśliwy jest ten człowiek, który umiera w iluzorycznym przekonaniu, że jego cele życiowe zostały osiągnięte, podczas gdy w rzeczywistości jest przeciwnie" ${ }^{27}$. Istota rozumna bowiem realizuje się przez rzeczywiste dobra swojej natury, stąd dążenie do celów wyznaczonych przez naturę może mu zapewnić spełnienie. Jeśli łączyła się z tym przyjemność, to jest ona dobrem dodatkowym; jeśli cele te wymagały trudu i poświęcenia, to nie tracą one swej szczęściodajnej funkcji ${ }^{28}$.

W panseksualistycznej mentalności ignoruje się jednak to, że przyjemność w życiu ludzkim związana jest $\mathrm{z}$ obiektywnym celem, do którego ona przynagla ${ }^{29}$. Tak np. przyjemność smakowania potrawy czy napoju przyporządkowana jest drugiemu i zasadniczemu celowi, którym jest zdrowie człowieka. Podobnie doznanie przyjemności seksualnej przyporządkowane jest drugiemu, obiektywnemu celowi - tworzeniu więzi międzyosobowej między kobietą i mężczyzną, między małżonkami oraz prokreacyjnemu otwarciu się na nowe życie, w którym miłość małżeńska dopełnia się przez miłość rodzicielską, kobiecość dopełnia się przez macierzyństwo, męskość - przez ojcostwo.

Odrzucenie teleologii natury ludzkiej prowadzi również do likwidacji etyki, gdyż w jej miejsce - jak było wyżej wspomniane - wchodzi umowa społeczna. Teleologia ukierunkowuje na obiektywne cele, czyli na to, co dla człowieka jako takiego jest dobre. Jeśli zgodnie z dogmatami empiryzmu dokonamy jej likwidacji, to mamy wtedy tylko fakty fizyczne, ale nie mamy już wartości, nie mamy rozróżnienia tego,

26 R. Spaemann, Granice, dz. cyt., s. 192-193.

27 R. Spaemann, Granice, dz. cyt., s. 193.

28 Jak się ma spełnianie swego życia do przyjemności i szczęścia zob. R. Spaemann, Szczęście a życzliwość. Esej o etyce, tłum. Jarosław Merecki SDS, Lublin 1997.

29 Por. T. Biesaga, Spór o dobro moralne: hedonizm - eudajmonizm - personalizm, w: T. Biesaga, Podstawy etyki i bioetyki, dz. cyt., s. 190-204. 
co moralnie dobre i złe, nie mamy powinności moralnej ani norm moralnych. W miejsce etyki wchodzi prawo stanowione, ustanawiane i dowolnie zmieniane. Nie mamy jakichś uniwersalnych norm kierujących naszym życiem i życiem społecznym. Nawet deklaracje podstawowych wartości, międzynarodowe konwencje czy konstytucje, które wyliczają najważniejsze dobra, wartości i normy ludzkie, mogą być zmienione. Zlikwidowanie teleologii prowadzi do zlikwidowania podstawy prawa naturalnego, a tym samym do zlikwidowania uniwersalnych norm czy wartości kierujących życiem ludzkości. Trudno się dziwić, że w empirycznych nurtach uprawiających etykę na wzór nauk ścisłych likwiduje się etykę na rzecz metaetyki, na rzecz analizy języka moralności.

Odarcie ciała ludzkiego z jego aksjologii w teoriach dualistycznych, w spirytualistyczno-naturalistycznych koncepcjach skutkuje wykorzystaniem wiedzy nauk medycznych i praktyki medycznej przeciw człowiekowi. Prowadzi to do niszczenia teleologii ciała ludzkiego w wyni$\mathrm{ku}$ ingerencji przez preparaty antykoncepcyjne oraz psychotropowe $\mathrm{e}^{30}$. Zniszczenia te idą $\mathrm{w}$ parze $\mathrm{z}$ niszczeniem przyrody.

Obok destrukcyjnych skutków antyteleologii niszczących ciało ludzkie i właściwy rozwój humanizmu ludzkiego dochodzi do niszczenia środowiska naturalnego, przyrody. Teleologia bytu, w tym istot żywych, broniła przyrodę przed samowolą człowieka. Kiedy jej brakło, nie widząc granic swej samowoli, człowiek przystąpił do rabunkowej i niszczącej eksploatacji. Szok ekologiczny uświadomił mu, że „skończoność świata, w którym żyjemy, nie godzi się z zasadniczo nieograniczoną ekspansją naukowego opanowywania świata bez śmiertelnego zagrożenia gatunku ludzkiego. Panowanie nad naturą staje się iluzoryczne, gdy rozumiemy je jako walkę przeciw naturze. Walkę tę człowiek może jedynie przegrać" $^{31}$.

Teleologia bytu, teleologia natury ludzkiej wyznaczała i wyznacza nam właściwe podejście do przyrody i do swego własnego rozwoju.

30 Por. J. Kożuchowski, Ingerencje techniczne w nature - ujęcie Roberta Spaemanna, „Zeszyty Naukowe Politechniki Śląskiej”, Seria: Organizacja i Zarządzanie z. 71, nr kol. 1917, 2014, s. 181-194.

31 R. Spaemann, R. Löw, Cele naturalne, dz. cyt., s. 352. 
Uzmysławiała, że jesteśmy w symbiozie z przyrodą przez naszą cielesność, a więc ochrona naszego zdrowia to równocześnie ochrona środowiska przyrodniczego, aby nie zostało zdewastowane i zatrute przez człowieka i przez to nie zniszczyło jego samego. „Myśl o uwolnieniu człowieka przez samo opanowanie przyrody jest zapomnieniem o tym, że sam człowiek jest częścią przyrody i dlatego opanowanie przyrody zawsze oznacza także opanowanie człowieka" ${ }^{32}$. Zignorowanie celów własnych istot żywych, celowości ekosystemów życia usunęło granice samowoli człowieka, zlikwidowało normy chroniące przyrodę, rośliny, zwierzęta i środowisko życia, i tym samym zlikwidowało normy chroniące cielesność, zdrowie, a nawet życie człowieka. Świadczą o tym powstałe na początku XX wieku okrutne ideologie eugenicznej selekcji i eliminacji ludzi ${ }^{33}$. To właśnie wewnętrzny cel medycyny, jakim jest zdrowie pacjenta, jest celem przyporządkowania nauk ścisłych i technicznych praktyce medycznej. On wyznacza racjonalność działań medycyny, przyporządkowuje nauki medyczne nie ich celom teoretycznym, ale celowi praktycznemu medycyny. Wykorzystanie wiedzy medycznej przeciwko temu celowi, nawet na życzenie pacjenta, jest irracjonalne i niemoralne.

\section{Teleologia warunkiem przetrwania filozofii współczesnej}

Czy można przeciwdziałać i zaradzić destrukcyjnym skutkom, jakie niesie zagubienie teleologii bytu w myśleniu filozoficznym? Spaemann formułuje w tym względzie zaskakującą radę. Jeśli chcemy skorzystać z pozytywnych refleksji nowożytnego i współczesnego myślenia filozoficznego, powinniśmy bronić go przed nim samym ${ }^{34}$. Zmierza ono bowiem do samozniesienia czy samounicestwienia, co jego zdaniem wystarczająco pokazał już Fryderyk Nietzsche. „Jeśli nie chcemy takiego samozniesienia - stwierdza Spaemann - to nie możemy rozumieć

32 R. Spaemann, R. Löw, Cele naturalne, dz. cyt., 355.

${ }_{33}$ Zob. T. Biesaga, Eugenika w propozycjach legalizacji prawa do zdrowej reprodukcji, „Logos i Ethos" 50 (2019) nr 2, s. 27-46.

34 Por. R. Spaemann, Kroki poza siebie. Przemówienia i eseje, t. 1, tłum. J. Merecki, Warszawa 2012, s. 13. 
nowoczesności przez odniesienie do niej samej, lecz musimy jej - oświecenia, emancypacji, praw człowieka, nauki i panowania nad przyrodą musimy tego wszystkiego bronić przed nimi samymi. Musimy je pojmować ideologicznie jako rozwinięcie pierwotnej prawdy o człowieku, której one nie ustanowiły. Przetrwają one w XXI wieku tylko wówczas, gdy odnajdą w tej prawdzie swoją miarę"35. Całą swoją filozofię traktuje Spaemann jako obronę oświecenia i współczesności przed nimi samymi. Sądzi on, że uwzględnienie zapomnianej prawdy o człowieku, której nie ustanawiamy, lecz ją zastajemy, która jest realnie obecna i sama się narzuca, daje możliwość krytycznej oceny i odnalezienia miary dla filozofii współczesnej oraz dla proponowanych przez nią wyzwoleńczych programów. „Nowoczesna świadomość - stwierdza filozof - waha się pomiędzy akosmicznym transcendentalizmem a redukcjonistycznym naturalizmem. Transcendentalizm - również $\mathrm{w}$ tej swojej odmianie, jaką jest analiza języka - pyta o «warunki możliwości», filozofię pojmuje jako teorię tego, co możliwe, jako zbiór twierdzeń, które są prawdziwe we wszystkich możliwych światach"36.

Tymczasem w realistycznym myśleniu Arystotelesa to realna rzeczywistość jest przed możliwością, a nie odwrotnie. „Możliwość znaczyła: «móc». «Może» tylko to, co jest rzeczywiste" ${ }^{37}$. Postawienie w filozofii nowożytnej i współczesnej możliwości przed rzeczywistością, jest - według Spaemanna - spadkiem po chrześcijańskiej teologii nominalistów. W imię absolutyzacji Boga jako przyczyny sprawczej teologia ta likwidowała teleologię stworzonej rzeczywistości. Istoty stworzone nie mogą posiadać wynikających z ich natury własnych celów, gdyż te ograniczałyby wszechmoc Boga. Bóg może wszystko to, co można pomyśleć. Kiedy jednak zawiesi się odwołanie do Boga, to same owe ludzkie możliwości są czystą, oderwaną od rzeczywistości abstrakcją. Przypisywanie człowiekowi możliwości boskich to uzurpacja, która w realizacji panowania nad przyrodą prowadzi do jej zniszczenia. Bez przywołania prawdy

\footnotetext{
35 R. Spaemann, Kroki poza siebie, dz. cyt., s. 12-13.

36 R. Spaemann, Kroki poza siebie, dz. cyt., s. 13.

37 R. Spaemann, Kroki poza siebie, dz. cyt., s. 13.
} 
o naturze istot żywych, o naturze człowieka, nie mamy miary ani kryterium dla wpisania naszych możliwości w harmonię z rzeczywistością, nie mamy miary dla odróżniania działań słusznych od niszczących realną rzeczywistość.

Tworzymy wtedy utopijne reguły, które są niewykonalne. Tak np. tzw. idealny utylitaryzm chce oceniać nasze czyny, odnosząc je do możliwie najlepszego świata. Kryterium ich oceny ma być optymalizacja pomyślanego stanu najlepszego świata. Do pozytywnej oceny czynu wymagane jest rozważenie niezliczonej liczby alternatyw i wyboru najlepszej a nich, czyli takiej, która miałaby się przyczynić do ukonstytuowania się w nieskończonym przebiegu czasu i wydarzeń najlepszego z możliwych światów. Takie wymaganie stawiane człowiekowi jest niewykonalne, nie mamy bowiem wiedzy dotyczącej wszelkich możliwych wariantów całościowego biegu świata. Nie tylko nie mamy nieskończonej wiedzy o wszystkich alternatywnych stanach świata, o jakiejś hierarchizacji tych stanów, ale nie mamy nawet wiedzy, w jaki sposób inni ludzie zareagują na nasze działanie i jakie z tego wynikną konsekwencje. Taką nieskończoną wiedzę o wszelkich całościowych stanach świata można przypisać tylko Bogu. Człowiek o skończonej świadomości nie jest zdolny posiadać takiej wiedzy, nie można jej też od niego wymagać i przypisywać mu roli Opatrzności Bożej ${ }^{38}$. Oderwanie naszych możliwości od natury ludzkiej i przypisywanie człowiekowi możliwości boskich czyni taką filozofię nie tylko bezużyteczną, ale i szkodliwą. Można bowiem w taki pusty racjonalnie program wpisać rewolucyjne, groźne utopie i niszczące ludzkość ideologie. Przeciw takiemu programowi trzeba przypomnieć, że możliwości ludzkie wyznacza jego realna natura, potencjalność tej natury i jej teleologiczne skierowanie do właściwego jej dobra.

Naturalizm, jako dialektyczna odwrotność transcendentalizmu, w odmienny sposób podważa realne możliwości człowieka wynikające $z$ natury jego bytu osobowego, ponieważ podporządkowuje jego naturę deterministycznym procesom przyrodniczym. Człowiek w tym ujęciu jest „wytworem ewolucyjnych procesów adaptacyjnych aparatu

38 Por. R. Spaemann, Granice, dz. cyt., s. 364-369. 
neurofizjologicznego, poznanie teoretyczne i intuicja moralna są modyfikacją służącą ich przetrwaniu, wolność generatorem przypadku w złożonych systemach, negatywność - właściwa oznaka ducha - fizykalną daną w mózgu"39. Naturalizm nie ma możliwości odkrycia obowiązujących nas powinności wobec realnego świata, wobec człowieka czy Boga. W dialektyce z transcendentalnym ujęciem wolności ludzkiej może on prowadzić do zniszczenia „ekologicznej niszy, w której umieszczona jest ludzka wolność" ${ }^{40}$. Należy więc ocalić naturalizm i transcendentalizm przed nimi samymi i przywołać pełniejsze doświadczenie bytu, które ujawnia się właśnie w jego teleologii. „Wyścig pomiędzy «kauzalno-mechaniczną», nastawianą na ingerencję a teleologiczną, skierowaną na rozumienie wizją przyrody - stwierdza Spaemann - będzie trwał dalej. [...] Podejście kauzalno-naukowe biegnie zasadniczo prędzej w tym wyścigu z podejściem teleologicznym. Ucieka ono ciągle teleologii. Gdy jednak gdzieś dojdzie i triumfalnie sądzi, że jest u celu, przydarza się mu to, co w wyścigu zająca z jeżem: jeż siedzi już u celu i woła: «już tu jestem!» ${ }^{41}$. Nie da się bowiem zignorować rzeczywistości, która trwa i upomina się o siebie oraz ujawnia się choćby w postaci szoku ekologicznego. Mimo że rzeczywistość upomina się o siebie, nie wiemy, czy sama obroni nas przed katastrofą. Zając może bowiem zignorować stojącego na jego drodze jeża i biec dalej ku przepaści. Potrzebny jest więc renesans teleologii w ujęciu bytu, w ujęciu natury człowieka, by chronić współczesną filozofię i kulturę przed samolikwidacją siebie oraz przed katastrofalnymi skutkami ślepego technokratyzmu względem przyrody i natury ludzkiej.

39 R. Spaemann, Kroki poza siebie, dz. cyt., s. 14.

40 R. Spaemann, Kroki poza siebie, dz. cyt., s. 15.

41 R. Spaemann, R. Löw, Cele naturalne, dz. cyt., s. 355. 


\section{Bibliografia}

Angier T. P. S., Book Reviews: A Robert Spaemann Reader: Philosophical Essays on Nature, God, and the Human Person, ed. and transl. by D. C. Schindler \& Jeanne Heffernan Schindler, OUP, Oxford 2015; „The Philosophical Quarterly” 68 (2018) No. 270, s. 194-196.

Biesaga T., Alasdaira MacIntyre’a krytyka etyki nowożytnej i współczesnej, w: T. Biesaga, Podstawy etyki i bioetyki, Kraków 2016, s. 15-29.

Biesaga T., Eugenika $w$ propozycjach legalizacji prawa do zdrowej reprodukcji, „Logos i Ethos" 50 (2019) nr 2, s. 27-46.

Biesaga T., Natura osoby ludzkiej a ulepszanie człowieka, w: Ulepszanie człowieka. Perspektywa filozoficzna, red. G. Hołub, P. Duchliński, Kraków 2018, s. 169-198.

Biesaga T., Spór o dobro moralne: hedonizm - eudajmonizm - personalizm, w: T. Biesaga, Podstawy etyki i bioetyki, Kraków 2016, s. 190-204.

Gondek P., Kontekst odkrycia przyczyny celowej, w: Spór o cel, red. A. Maryniarczyk SDB, K. Stępień, P. Gondek, Lublin 2008, s. 99-118 (Zadania Współczesnej Metafizyki, 10). Jakuszko H., Źródła i skutki odrzucenia przyczyny celowej w filozofii nowożytnej, w: Spór o cel, red. A. Maryniarczyk SDB, K. Stępień, P. Gondek, Lublin 2008, s. 35-56 (Zadania Współczesnej Metafizyki, 10).

Kożuchowski J., Ingerencje techniczne w naturę - ujęcie Roberta Spaemanna, „Zeszyty Naukowe Politechniki Śląskiej”, Seria: Organizacja i Zarządzanie z. 71, kol. 1917, 2014, s. 181-194.

Krąpiec M. A., Problematyka celu w wyjaśnianiu filozoficznym, w: Spór o cel, red. A. Maryniarczyk SDB, K. Stępień, P. Gondek, Lublin 2008, s. 17-34 (Zadania Współczesnej Metafizyki, 10).

Ramelow A. OP, Teleology and transcendence: the thought of Robert Spaemann, „Communio: International Catholic Review” 45 Fall-Winter 2018, s. 567-612.

Spaemann R., Granice. O etycznym wymiarze działania, tłum. J. Merecki, Warszawa 2006. Spaemann R., Kroki poza siebie. Przemówienia i eseje, t. 1, tłum. J. Merecki, Warszawa 2012.

Spaemann R., Löw R., Cele naturalne. Dzieje i ponowne odkrycie myślenia teleologicznego, tłum. A. Półtawski, Warszawa 2008.

Spaemann R., Osoby. O różnicy między czymś a kimś, tłum. J. Merecki SDS, Warszawa 2001. Spaemann R., Szczęście a życzliwość. Esej o etyce, tłum. J. Merecki SDS, Lublin 1997. 
Teinert Z., Spór o naturę. Wokół konstytucji osoby w ujęciu Roberta Spaemanna, Poznań 2003.

Wróblewski Z., O pewnej próbie obrony wyjaśniania teleologicznego, „Roczniki Filozoficzne" 60 (2012) nr 4, s. 339-359.

\section{Abstrakt \\ Roberta Spaemanna próba przywrócenia myślenia teleologicznego we współczesnej filozofii}

Artykuł rekonstruuje dzieje likwidacji teleologii bytu w myśleniu filozoficznym. Wskazuje na teoretyczne źródła tego procesu oraz na jego katastrofalne skutki praktyczne. Już pod koniec średniowiecza św. Tomasza genialna synteza teleologii Arystotelesa z chrześcijańską nauką o stworzeniu została zakwestionowana przez teologów nominalistów. Dzieło destrukcji kontynuowała filozofia nowożytna i współczesna. Dziś bez większego trudu można zauważyć, że proces ten teoretycznie prowadzi do samolikwidacji tego myślenia, a praktycznie do katastrofalnych skutków niszczących przyrodę i cielesność człowieka. Przywrócenie myślenia teleologicznego w filozofii pozwala określić granicę, miarę, kryteria i normy aktywności człowieka względem przyrody oraz względem istot żywych i względem niego samego.

\section{Słowa kluczowe}

teleologia, bonum diffusivum sui, partycypacja, nominalizm, naturalizm, transcendentalizm, antropomorfizm, realność, możliwość, samozachowanie, samotranscendencja

\section{Abstract \\ Robert Spaemann's an attempt to restore the teleological thinking in modern philosophy}

The paper is reconstructing the process of elimination of teleology in philosophical thinking. It shows theoretical source of this process and its catastrophic practical effects. In the end of Middle Ages, St. Thomas' genies synthesis of Aristotle's teleology of being with Christian teaching of creation of the world, was contested by nominalists 
theologian. This process of destruction was continued by modern and contemporary philosophy. Today is easy to see the theoretical contradiction in this thinking and practical disastrous effects on natural and human environment. The restoring of teleological thinking in philosophy, give us possibility to define boundary line, measure, criterions and norms for human activity, to take proper care for nature, for living creatures and for human being himself.

\section{Keywords}

teleology, bonum diffusivum sui, participation, nominalism, naturalism, transcendentalism, anthropomorphism, reality, possibility, self-preservation, self-transcendence 